\title{
HANDEL RECOVERING: FRESH LIGHT ON HIS AFFAIRS IN 1737
}

\author{
I L I A S CHRISSOCHOIDIS
}

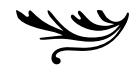

The summer and autumn of 1737 remain a foggy patch in Handel biography owing to poor documentation and Handel's absence from London. We do not know whether his illness led to a rapprochement with the 'Nobility' opera, how his visit to Aix-la-Chapel complicated the new opera season or, especially, whether these developments relate to Farinelli's defection to Spain. This shaky factual ground also restricts our understanding of later events such as Handel's lucrative benefit in March 1738 and the celebrated Roubiliac statue in Vauxhall Gardens. Thanks to surviving issues of the Daily Advertiser, however, we now can replenish the documentary pool and re-examine Handel's affairs and their context during this period.

\section{HANDLING ILLNESS DURING THE OPERASEASON ( A P RIL-JUNE)}

That Handel collapsed in April 1737 is no surprise. His workload that season had been exceptionally heavy. He had produced Arminio and Giustino, completed Berenice, revived Partenope, and continued with Il Parnasso in Festa, Alexander's Feast, the revised Il Trionfo del Tempo e della Verita and Esther. For the latter group of works, he also had performed organ concertos. Considering his advanced age (fifty-two), careless diet and financially ruinous competition with the 'Nobility' opera, a health breakdown was likely.

The exact moment of crisis has yet to be determined, although it probably coincided with the short-lived pasticcio Didone (13, 20 and 27 April). Turning a suggestion by Burney into a fact, Deutsch writes that 'Handel was unable to direct the opera: it was on the 13th [of] April that he had the stroke paralysing his right arm'. ${ }^{1}$ However, the original statement in the General History of Music reads 'perhaps this opera was brought out during Handel's illness' and is meant to explain the documentary silence on Didone: 'The songs were never printed, and no record remains of the existence of this opera but the advertisements of its performance, by which it cannot be discovered whether it was an entire work, by one composer, or a pasticcio by many composers'. ${ }^{2}$ Donald Burrows suggests the attack 'probably occurred soon after the second performance of Didone' (20 April), the one closest to the first surviving report on Handel's collapse (26 April). ${ }^{3}$ This is a sensible proposal, but it rests on the assumption that celebrity news spread quickly. Yet reports on Handel's collapse appeared as late as 14 May in the press (see below). And with the season still open, the composer had every reason to keep his health problems a well-guarded matter.

A new hint emerges from Didone's erratic publicity in the Daily Advertiser. While the premiere was first announced as 'By Command of their Royal Highnesses' (Saturday 9 April), this line disappears from advertisements on Tuesday 12 and Wednesday 13 April.4 The pattern switches for Didone's second night,

\footnotetext{
1 Otto Erich Deutsch, Handel: A Documentary Biography (London: Adam and Charles Black, 1955), 431; see also 433.

2 Charles Burney, A General History of Music, from the Earliest Ages to the Present Period. Volume the Fourth (London: the author, 1789), 407-408.

3 Donald Burrows and Rosemary Dunhill, eds, Music and Theatre in Handel's World: The Family Papers of James Harris, 1732-1780 (Oxford and New York: Oxford University Press, 2002), 26-27.

4 The Daily Advertiser (hereafter DA), nos 1936, 1938, 1939, all on page [1].
} 
whose advertisements promised a regular performance (Friday and Saturday, 15-16 April) but restored the command line exactly on the day of the performance (Wednesday 20), signalling princely attendance. ${ }^{5}$ Last-minute changes such as these were not exceptional for London theatres. However, these two coincide with the period of Handel's collapse and involve a patron newly committed to the composer. For the first time since 1734, the Prince of Wales offered Handel a bounty of $£ 250^{6}$ and regularly attended his performances during 1736-1737.7 In the month preceding Didone alone, he had ordered three commands and visited Handel's productions once a week. The Daily Advertiser reports three of these:

[Wednesday 2 March:] Last Night their Royal Highnesses the Prince and Princess of Wales went to the Theatre Royal in Covent Garden to hear the Opera of Justin. (no. 5936, 3/iii/37, [2])

[Wednesday 16 March:] Last Night their Royal Highnesses the Prince and Princess of Wales went to the Theatre Royal in Covent Garden, where Mr Dryden's celebrated Ode called Alexander's Feast was performed with great Applause, and to the Satisfaction of a numerous Audience. (no. $5948,17 / \mathrm{iii} / 37,[2])^{8}$

[Wednesday 23 March:] Yesterday their Royal Highnesses the Prince and Princess of Wales went to the Theatre Royal in Covent Garden, to hear the new Oratorio there, called, Il Triomfo [sic] del Tempo e della Verita, which was performed to the Satisfaction and great Applause of the whole Company. (no. 5954, 24/iii/37, [2])

This level of support suggests that the cancellation of the 13 April command performance was owing to exceptional reasons such as the onset of Handel's illness, anytime between late Friday and Monday. What strengthens 9-11 April as a potential time frame for Handel's collapse is that it came right at the end of Passion Week, when the composer performed three different works in four successive days (Monday to Thursday 4-7 April). The physical strain of a gruelling schedule together with the anticipated bout of gluttony on Easter Sunday were high risk factors for a stroke.

Recovery seems to have been erratic. By late April Handelians were impressed with the artist's medical progress and anticipated the premiere of Berenice on 11 May. ${ }^{9}$ Their optimism found its way in the London Daily Post of 30 April, which reports Handel 'in so fair a way of recovery, that it is hoped he will be able to accompany the opera of Justin on Wednesday next, the 4 th of May; at which time we hear their Majesties will honour that opera with their presence'. ${ }^{10}$ Things did not go exactly as planned, however. The Daily Advertiser confirms performances of Justin not only on 4 but also on 11 May ('This Evening will be perform'd ... At the Theatre Royal in Covent-Garden, Justin'), ${ }^{11}$ thus delaying the opening of Berenice. Moreover, the absence of advertisements, highly atypical for royal commands, supports Burney's misgivings about their Majesties'

5 DA, nos 1941, 1942, 1945, [1], [2], [2], respectively.

6 Carole Taylor, 'Handel and Frederick, Prince of Wales', The Musical Times 125 (February 1984), 91.

7 Alan Yorke-Long, 'The Opera of the Nobility' (unpublished dissertation, Oxford University, 1951), 102, cited in Thomas McGeary, 'Handel, Prince Frederick, and the Opera of the Nobility Reconsidered', Göttinger Händel-Beiträge 7 (1998), 176; Arthur H. Scouten, ed., The London Stage, 1660-180o. Part 3 (Carbondale, IL: Southern Illinois University Press, 1961), 613-656.

8 An identical report appeared in The Daily Journal of the same date: Walter Eisen and Margaret Eisen, eds, Händel Handbuch, Band 4: Dokumente zu Leben und Schaffen (Kassel, Basel and London: Bärenreiter, 1985), 277. The London Daily Post of 17 March published an expanded story, confirming that the princely couple 'seem'd to be highly entertain'd, insomuch that his Royal Highness commanded Mr. Handel's Concerto on the Organ to be repeated, and intends to Honour the same with his Presence once again, as likewise the new Oratorio call'd Il Trionfo del Tempo e della Verita, which is to be perform'd on Wednesday next': excerpted in Scouten, ed., London Stage, 649, and fully reprinted (as from 'Eine Londoner Zeitung') in Eisen and Eisen, eds, Händel Handbuch, 277-278.

9 The 4th Earl of Shaftesbury to James Harris, 30 April 1737: Burrows and Dunhill, eds, Handel's World, 27.

10 Burney, History, 408.

11 DA, no. 1957, Wednesday 4 May 1737, [1]; no. 1963, Wednesday 11 May 1737, [1]. 
presence at either performance. ${ }^{12}$ The most likely reason for this change was Handel's slow recovery ('not well enough to play the harpsicord himself' ${ }^{13}$ ), which justified the alarming report in the London Evening-Post only days later:

[Saturday 14 May:] The ingenious Mr. Handell is very much indispos'd, and it's thought with a Paraletick Disorder, he having at present no Use of his Right Hand, which, if he don't regain, the Publick will be depriv'd of his fine Compositions. (no. 1481, 12-14/v/37, [1]; also in Deutsch, Handel, 434)

In contrast to the low-profile Didone, described by Shaftesbury a 'very heavy' opera, ${ }^{14}$ Berenice premiered 'By His MAJESTY's Command'. ${ }^{5}$ Whether its debut on 18 May signalled Handel's recovery or was a desperate effort to attract crowds before the season ended is hard to tell. We should notice, however, that royal attendance was a strong gesture of support. On 17 May, their Majesties had appeared at Sabrina, the 'Nobility' Opera's current production (DA, no. 1968, 17/v/37, [2]). Their attendance at operas two nights in a row was unusual and indicates a strong interest in Handel's premiere. Both visits were duly reported in the press:

[Monday 16 May:] We hear that their Majesties and the rest of the Royal Family will be present Tomorrow at the Opera of Sabrina, with the Interlude of Grullo and Moschetta, at the Hay-Market. (DA, no. 1967, 16/v/37, [1])

[Tuesday 17 May:] Last Night the King, Queen, and Princesses, went to the Opera in the Haymarket. And this Evening their Majesties will be at the Opera in Covent Garden. (The Daily Gazetteer, no. 593, 18/v/37, [1]; also in Deutsch, Handel, 434-435.)

Royal interest apart, Berenice had a short life, with repeat performances on 21 and 25 May and 15 June. The composer's absence from the orchestra pit due to performing difficulties (reported by Shaftesbury on 12 May) presumably affected its career. Given this poor outcome and the decision to end by early June ('Mr Handel designs to play hardly more than five times this season'), ${ }^{16}$ it is remarkable that Handel continued to offer performances until 25 June. Was this an effort to squeeze the last guinea out of the season? Or rather was he showing off his stamina during negotiations for $1737-1738$ ? For Handel was already in discussions with the collapsing 'Nobility' opera about a successor scheme that also included Caffarelli. ${ }^{17}$ On 11 June 1737, the Earl of Shaftesbury assured James Harris that 'things will turn out well', as the majority of the opera party was 'so desirous of hearing good music'. ${ }^{18}$ The splendid news reached the public two days later:

[Monday 13 June:] We hear that the Managers of the Opera in the Hay-Market have contracted with Signior Caffaral [sic], a famous Singer at Rome, who was brought up with Signior Farinello, to sing in our Operas here the next Winter, and that Mr. Handel is to compose the Musick. (DA, no. 1991, 13/vi/37, [1]; reprinted in The Grub-street Journal, no. 390, 16/vi/37, [2] $)^{19}$

12 Burney, History, 408.

13 The 4th Earl of Shaftesbury to James Harris, 12 May 1737: Burrows and Dunhill, eds, Handel's World, 29.

14 The 4th Earl of Shaftesbury to James Harris, 26 April 1737: Burrows and Dunhill, eds, Handel's World, 26.

$15 D A$, no. 1969, Wednesday 18 May 1737, [2].

16 The 4th Earl of Shaftesbury to James Harris, 12 May 1737: Burrows and Dunhill, eds, Handel's World, 29.

17 'SATURDAY, May 21 ... We hear that the Directors of his Majesty's Opera-house, have engaged, for the ensuing season, the famous Gaffariello, reputed the best singer in Italy.' LP. [The London Post] (The Grub-street Journal, no. 387, Thursday 26 May 1737, [2]); see also Burney, History, 412-413.

18 The 4th Earl of Shaftesbury to James Harris, 11 June 1737: Burrows and Dunhill, eds, Handel's World, 31.

19 Reprinted in Donald Burrows, 'Handel and the London Opera Companies in the 1730s: Venues, Programmes, Patronage and Performers', Göttinger Händel-Beiträge 10 (2004), 160. 
The stress of negotiations with former rivals (also known as 'the Goths'20), which yielded a lucrative commission of two operas for $\mathfrak{E} 1,000$, along with the administrative burden of protracting the season for two months after his attack, must have complicated Handel's recovery. So much so that, 'when the heats of the Summer 1737 came on, the Disorder seemed at times to affect his Understanding..$^{21}$

\section{HEALTH PILGRIMAGE AND LONDON'S NEW OPERA ( A UGUST-NOVEMBER)}

Handel was pressed to visit a number of spas, both in England and abroad. The first stop on his health tour was Tunbridge Wells, as reported by Hawkins in 1776 ('he was advised to the use of the waters at Tunbridge' ${ }^{22}$ and now confirmed in a recently published letter by James Upton, who had met and socialized with Handel at the end of August ('we dind [sic] together every day in the week'). ${ }^{23}$ Two hitherto unknown reports in the Daily Advertiser help enrich and complicate this image:

[Thursday 4 August:] Yesterday Mr. Handell set out for the Bath for the Recovery of his Health, he having lately been struck with a dead Palsy on one Side. (no. 2037, 5/viii/37, [1])24

[Monday 15 August:] 'Tis with the greatest Pleasure we can assure the Publick, that the Report which was spread concerning Mr. Handel's being seiz'd with a dead Palsy on one Side, is altogether groundless, that Gentleman being now at Tunbridge in good Health. (no. 2045, $15 /$ viii $/ 37,[1])$

The composer thus left London on Thursday 4 August and following a brief stay at Bath moved to Tunbridge (Wells) towards the end of the next week (about the same time as John Upton).

It is unclear whether 'dead Palsy' alludes to his collapse in April or to a fresh incident; 25 and whether the retraction by default downgrades his visits to mere spa tourism ("twas the fashion to Tunbridge to go'26). The latter seems unlikely, though, considering that Shaftesbury in 1760 and Hawkins in 1776 affirm that 'the heats of the Summer 1737' exacerbated Handel's 'Disorder' and, owing to unsuccessful medical treatment, the composer 'was prevailed on, but with great difficulty, to resort to Aix la Chapelle'.27

One feels the reassuring tone was meant for London's opera constituency, who had strong interest in the forthcoming season. The bitter operatic rivalry of four years past was giving way to cooperation. With the new company relying on Handel for fresh operas, his recovery was a pressing matter, particularly so after fears about Farinelli's defection to the Spanish court began to spread in London. Rumours about the singer's return to the Continent had circulated as early as February:

[Miss] Fidg[et]. Why, that Farinelli is going away.

[Miss] Triffle]. Oh, good God! I hope not - I would not have him go, without seeing him once more in Arti sursi [Artaxerxes] for all the world..$^{28}$

20 Burrows and Dunhill, eds, Handel's World, 31.

21 'The Earl of Shaftesbury's Memoirs of Handel': Deutsch, Handel, 846.

22 John Hawkins, A General History of the Science and Practice of Music (London: T. Payne, 1776), volume 5, 326.

23 John Upton to James Harris, 1 September 1737: Burrows and Dunhill, eds, Handel's World, 36.

24 Reprinted in The London Evening-Post, no. 1517, Thursday 4 - Saturday 6 August 1737, [2], where the weekday is specified as 'Thursday'. Contemporary references to Bath occasionally use the definite article.

25 The Grub-street Journal, which reprinted both passages, promptly attacked the Daily Advertiser for spreading contradictory news: no. 398, Thursday 11 August 1737, [2]; no. 399, Thursday 18 August 1737, [2].

26 'Fashion. A Ballad', in The Gentleman's Magazine: And Monthly Oracle (1737), 716.

27 Shaftesbury, 'Memoirs', in Deutsch, Handel, 846; Hawkins, History, volume 5, 326.

28 The Grub-street Journal, no. 373, Thursday 17 February 173[7], [1]; see also Thomas McGeary, 'Farinelli in Madrid: Opera, Politics, and the War of Jenkins' Ear', The Musical Quarterly 82/2 (1998), 385. 
Still, Farinelli had promptly re-entered England after his French sojourn in summer 1736 and given his contractual obligations for 1737-1738 as well as his close ties with the British aristocracy, he was expected back to London in the late autumn:29

[Thursday 9 June:] We hear the famous Farinello attends his Grace the Duke of Leeds this Season to Scarborough, and to his Grace's Seat in the North. (The London Evening-Post, no. 1492, $7-9 /$ vi/37, [1])

[Thursday 9 June:] We hear that Signior Farinello intends to set out for the Court of Spain, and stay there till the Operas begin here next Season. (DA, no. 1988, 9/vi/37, [1]; reprinted in The Grub-street Journal, no. 390, 16/vi/37, [2])

By late summer, nonetheless, worries about his attachment to the Spanish crown swelled. With Caffarelli, the season's new attraction, still in Italy, and Farinelli bewitched by Spain, Handel's medical condition assumed new urgency for opera-goers in London. The 15 August report in the Daily Advertiser quelled their fears that the composer, too, might be unavailable in autumn 1737. Things turned out differently, however, forcing him to exchange Tunbridge for Aachen (Aix-la-Chapel), whose baths were strongly recommended for 'pluretic and rheumatic Disorders' and in particular 'spasmodic contractions, palsies or other nervous imbecilities'. ${ }^{\circ}$

No details about Handel's move to Aix-la-Chapel survive. It was probably a last-minute decision wisely kept away from the press. Mainwaring and Hawkins are explicit only about its results and duration: a full recovery bordering on the miraculous in the space of six weeks. ${ }^{31}$ Such an outcome seemed hardly unusual for a city named (in German) 'Aach or Aachen; as is supposed, from Ach, an interjection of surprise; as if one should say, Hah! or hah! hah! being surprised with the unexpected heat or cold of any thing.' ${ }^{32}$

Known as the hottest springs in Europe, the waters of Aix contained sulphur 'in great Plenty'. ${ }^{33}$ Their steam baths promised a tough experience to the visitor, as vapour temperature rose up to $128^{\circ} \mathrm{F} .{ }^{34} \mathrm{Handel}$ 's protracted use of them ('three times as long as hath ever been the practice'35) was impressive, to say the least..$^{36}$ The reported length of this treatment ('about six weeks' 37 ) is accurate too: 'The first season for them begins about the middle of May, and the second about the middle of August, and each continues about six weeks' $3^{8}$ That Handel missed the season's beginning supports the view that he had been pushed to visit Aix-la-Chapel in late summer and the withdrawal of $\mathfrak{E} 150^{2}$ from his cash account on 1 September very likely reflected preparations for his trip. 39

29 Burrows incorrectly states that, 'By the end of the $1736-7$ season . . . the Nobility Opera also knew that Farinelli would not continue' ('London Opera Companies', 161). In 1770, Farinelli himself assured Burney that 'he went into Spain ... with a full design to return into England, having entered into articles with the nobility, who had then the management of the opera, to perform the ensuing season': Charles Burney, The Present State of Music in France and Italy: Or, The Journal of a Tour through those Countries, undertaken to collect Materials for A General History of Music (London: T. Becket, 1771), 209; see also, History, 413. His version is now confirmed by contemporary documents reprinted in McGeary, 'Farinelli in Madrid', 389-394.

30 Charles Perry, An Enquiry into the Nature and Principles of the Spaw Waters... A Cursory Enquiry into the Nature and Properties of the Hot Fountains at Aix la Chapelle (London: James, John and Paul Knapton, 1734), 110; C[harles] Lucas, An Essay on Waters (London: A. Millar, 1756): 'Of the Baths of Aken', 152.

31 [John Mainwaring], Memoirs of the Life of the Late George Frederic Handel (London: R. and J. Dodsley, 1760), 122-123; Hawkins, History, volume 5, 326.

32 Lucas, Waters, 10.

33 Perry, Enquiry, 88; on the effects of its waters, see 109-111.

34 Lucas, Waters, 58.

35 [Mainwaring], Handel, 122.

36 Lucas notes that 'The more aged, robust, corpulent, and full, bear and require bathing the longest' (Waters, 170).

37 [Mainwaring], Handel, 123.

38 Tobias Smollett, The Present State of All Nations (London: R. Baldwin et al., 1768-1769), volume 5, 20.

39 Ellen T. Harris, 'Handel the Investor', Music \& Letters 85/4 (2004), 538, 565. 
Arriving at Aachen in early September and 'determined to stay ... till the end of six weeks' ${ }^{40}$ Handel could hardly have contemplated a visit to Elbing, well over 600 miles eastwards. A supposed letter by John Christopher Smith Sr, reporting him there in mid-October ${ }^{41}$ must indeed qualify as a 'fiction'. ${ }^{42}$ Besides, waiting for him in London after years of dwindling revenue was a salary of $\mathfrak{k}_{1,000}$ (equal to the royal subsidy for operas). This alone could keep Handel focused on his main objective, returning to England 'in perfect health'.43

If anything, Londoners expected him up and running by late October, as a report in the Daily Advertiser establishes:

[Monday 26 September:] We hear that the King's Theatre in the Hay-Market will be open'd with a new Opera of Mr. Handel's composing, on Tuesday the 25th of October next, but without Signior Farinello, who has engag'd himself to stay in Spain this Winter. (no. 2081, 26/ix/37, [1])44

The good news certainly boosted morale after Farinelli's betrayal (Spain's privileges bestowed on the castrato were duly reported in the press, including the London Evening-Post of the same day45). We should not underestimate the fact that at this moment Handel was not only redeemed (welcomed back to the King's Theatre) but also a redeemer, since he had never been associated with the prodigal singer.

The report also raises questions about the agreement between Handel and his new employers. Did he promise to complete a new opera specifically for the season's opening? New works were typically offered in the second part of the season, but the consolidation of the two opera companies might have called for an exception. If so, when was he able to start composing, given the problems with his right hand and his subsequent health tour? Did Handel inform his employers about moving to Aix and did he keep them updated on his progress and estimated arrival? Or should we presume that the Farinelli-induced chaos directed attention away from Handel, who thus could leave the country without any publicity and come back to save the day?

The fact remains that the new company opened without a Handel premiere and later than originally planned. An administrative reshuffling could explain these changes. According to Burney, 'Heidegger had now undertaken the management of the opera ... which the nobility had abandoned, in consequence of Farinelli's detention at Madrid'. ${ }^{46}$ Yet contributions for the 1737-1738 season made by the Duke and Duchess of Bedford support Robert D. Hume's view that financial responsibility for the company remained in the hands of noblemen. ${ }^{47}$ The truth must stand somewhere in-between, for Burney enlists the testimony of Caffarelli and a satirical letter from December 1737 identifies Heidegger as an administrator of the Haymarket opera, ${ }^{48}$ whereas Hume bases his suggestion on the single example of the Bedfords.

It is undeniable, however, that Farinelli's absence forced changes to the plans for the autumn, leaving the company with only one castrato. Caffarelli reached London around 10-11 October (not 1 November, as given in Deutsch ${ }^{49}$ ) and immediately started rehearsals:

40 Hawkins, History, volume 5, 326.

41 Eisen and Eisen, eds, Händel Handbuch, 284.

42 Winton Dean, Handel's Operas, 1726-1741 (Woodbridge: Boydell, 2006), 393.

43 Hawkins, History, volume 5, 326.

44 Burrows alludes to the first part of the report in 'London Opera Companies', 162.

45 Burney, History, 414; see also reprinted news on the topic from 17 September in The Grub-street Journal, no. 404, Thursday 22 September 1737, [3].

46 Burney, History, 418.

47 Robert D. Hume, 'Handel and Opera Management in London in the 1730s', Music \& Letters 67/4 (1986), 358.

48 Common Sense: Or, The Englishman's Journal, no. 45, Saturday 10 December 1737, [1]. Heidegger's prominence in operatic affairs at this period is established by a report on the 'Nobility' opera's last production, Sabrina, which was rehearsed in his 'Appartments [sic], to a numerous and very splendid Audience of Ladies and Gentlemen': $D A$, no. 1950, Tuesday 26 April 1737, [1].

49 Handel, 441. Deutsch cites Burney's History, which reads 'Arsace, a pasticcio, was advertised and performed October 29th; and November 1st, Caffarelli was come over as first singer; and Pescetti was the nominal composer' (418). Given 
[Saturday 15 October:] The Beginning of this Week Signior Caffarielli, a famous Singer, arriv'd here from Italy. He has practised the Part he is to sing in the new Opera, and meets with a universal Applause, the Virtuosos in Musick being of Opinion he sings as well as Farinello. (DA, no. 2098, $15 / \mathrm{x} / 37,[1])$

A week later, the season's first production was announced in full detail:

[Monday 17-Saturday 29 October]

AT the KING's THEATRE in the HAY-MARKET, on Saturday the 29th Day of October, will be perform'd a new OPERA, call'd / ARSACES. / Pit and Boxes to be put together; and no Persons to be admitted without Tickets, which will be deliver'd that Day, at the Office in the Hay-Market, at Half a Guinea each. Gallery 5s. / By HIS MAJESTY’s COMMAND, / No Persons whatever to be admitted behind the Scenes. / The Gallery will be open'd at Four o' Clock. Pit and Boxes at Five. / To begin at Six o' Clock. / Note. The Silver Tickets will be deliver'd to the Subscribers on Monday the 24th of October, paying their Subscription at the Office in the Hay-Market, and every Day after till the Day of Performance, where Subscriptions will be taken in. (DA, no. 2099, 17/x/37, [2])

Burney calls Arsaces a pasticcio and identifies Pecsetti as its 'nominal composer'; 50 Angelo Corri was responsible for the libretto. ${ }^{51}$ It is not known if the opera featured music by Handel. The premiere was changed from 25 to 29 October, ${ }^{52}$ probably to coincide with the return of the Royal family to St James's palace and the celebrations for the king's birthday on Sunday 30 October:

[Saturday 29 October:] We hear their Majesties will be at the Opera in the Hay-Market this Evening. (DA, no. 2110, 29/x/37, [1])

On Saturday Night their Majesties were at the Opera in the Hay-Market. Great Part of Pall-Mall, thro' which their Majesties pass'd was illuminated. The celebrated Sig. Caffarielli perform'd in the Opera for the first time with universal Applause. (DA, no. 2111, 31/x/37, [1])

Others thought differently. Dismissing Arsaces as 'an old opera', the Earl of Shaftesbury wrote that the house 'was but thin' and Caffarelli 'did not please extreamly'.53 Following a repeat on Tuesday 1 November, ${ }^{54}$ no more performances were listed in the Daily Advertiser for 1737.

Handel probably reached the city just in time for the premiere. 55 On Friday 28 October, the London Daily Post announced that 'Mr. Handel, the Composer of the Italian Music, is hourly expected from Aix-la-Chapelle'. ${ }^{6}$ Considering eighteenth-century travel conditions, 'hourly' can only signify that he had already crossed the Channel and his arrival depended on local factors, such as delays in the customs and

Burney's meticulous use of contemporary newspapers, I wonder if the mistake here is one of reverse punctuation. Exchanging the position of semicolon and comma for 'and November 1st' would settle the problem.

50 Burney, History, 418.

51 'The worthy Angelo Cori is less known, and consequently less admired; but I can give no better an Idea of his excellent Parts and fine Turn of Nonsense, than by quoting one of his Songs in the last delightful Opera of Arsaces, Act 1st. Scene 4th. Page 13th': Commons Sense, no. 45, Saturday 10 December 1737, [1]; reprinted in Common Sense: Or, The Englishman's Journal (London: J. Purser, and G. Hawkins, 1738), volume 1, 309-310. Deutsch, however, writes 'text by Salvi, altered by Rolli': Handel, 441.

$52 D A$, no. 2110, Saturday 29 October 1737, [1].

53 Burrows and Dunhill, eds, Handel's World, 38. Italophiles had, of course, every reason to supplant grief over Farinelli's loss with attachment to the new singer ('When you speak of Caffarielli with her [Madam Brown], tell her, if you please, much that is good, for he is her favourite': Prince Cantemir to Marchioness Monconseil, 3 November 1737, in Lowell Lindgren, 'Musicians and Librettists in the Correspondence of Gio. Giacomo Zamboni (Oxford, Bodleian Library, MSS Rawlinson Letters 116-138)', [Royal Musical Association] Research Chronicle 24 (1991), 169.)

$54 D A$, no. 2112, [2].

55 Burrows is unnecessarily sceptical (or partially informed) about this point: 'Opera Companies', 162.

56 Burney, History, 418. 
muddy roads. His identification as 'Composer of the Italian Music' was a shrewd reminder of his new role in the Haymarket opera and given the festivities for the king's birthday, he had every reason to register his comeback at this particular moment. Ten days later, on 7 November, the same paper confirmed that he was 'greatly recovered in his Health'.57

Unfortunately for the opera manager(s), Handel arrived without a new work (composition on Faramondo began two weeks later). The company had been on shaky ground well before the Queen's death on 20 November, ${ }^{58}$ which effected the closure of London's theatres. An effort to revive Sabrina led nowhere; according to Burney, the production was 'often advertised in November' but 'deferred from time to time'.59 The Daily Advertiser featured the last such announcement:

[Friday 18 November:] The Opera of Sabrina, advertis'd for Tomorrow, is deferr'd till Tomorrow Se'ennight. (no. 2127, 18/xi/37, [1])

The unexpected death of Caroline probably saved the company from further embarrassment, allowing time for a comeback in early January with Faramondo. As for Handel, he found himself at the centre of a national event: his commissioned Funeral Anthem was widely praised and generated enough good will to turn his benefit of 28 March 1738 into a personal triumph.

It says a lot about the social dynamics of the period that 1737-1738 yielded more financial rewards for Handel than any of the seasons during which he produced his own entertainments. With a salary of $\mathfrak{E} 1,000$ for two operas, a benefit yielding at least $£ 800^{60}$ and $£ 600$ from his royal pensions, Handel was compensated for the losses of previous years and had every reason to look to the future with renewed optimism.

57 Burney, History, 418.

58 'Last Night at Ten o'Clock died of a Rupture, and Mortification of the Bowels, inexpressibly lamented, Her Most Sacred Majesty WILHELMINA DOROTHEA CAROLINA, Queen Consort of Great Britain, \&c. aged 55 Years, 8 Months, and 13 Days': DA, no. 2129, Monday 21 November 1737, [1].

59 Burney, History, 418.

60 Hume, 'Opera Management', 360. 